\begin{tabular}{cc|c}
\hline Tar. Bil. Der. & Tarım Bilimleri Dergisi & Journal of Agricultural Sciences \\
& $\begin{array}{c}\text { Dergi web sayfası: } \\
\text { www.agri.ankara.edu.tr/dergi }\end{array}$ & Journal homepage: \\
& www.agri.ankara.edu.tr/journal
\end{tabular}

\title{
Examining of Relationships Among Traits Using Correlation, Path and Principal Components Analysis Methods in Turkish Opium Poppy (Papaver somniferum L.) Cultivars
}

\author{
Nimet KARA ${ }^{\mathrm{a}}$, Hasan BAYDAR ${ }^{\mathrm{a}}$ \\ ${ }^{a}$ Suleyman Demirel University, Faculty of Agriculture, Department of Field Crops, Cunur Campus, 32260, Isparta, TURKEY
}

\section{ARTICLE INFO}

Research Article $\quad$ DOI: 10.15832/ankutbd.446462

Corresponding Author: Nimet KARA, E-mail: nimetkara@sdu.edu.tr, Tel: +90 (246) 2118595

Received: 18 May 2015, Received in Revised Form: 22 August 2017, Accepted: 19 September 2017

\begin{abstract}
Opium poppy is an important medicinal plant because of its very valuable pharmaceutical alkaloids such as morphine, codeine, and papaverine, etc. The research was carried out with the aim to examining the relationships between capsule yield, some other yield and quality traits by means of correlation, path and principal components analysis (PCA) in fifteen opium poppy (Papaver somniferum L.) cultivars registered in Turkey. The experiments were conducted designed according to a randomized complete block with three replications during 2012/13 and 2013/14 growing years in Isparta conditions.

In the research, there were significant positive correlations between capsule yield and capsule width, and 1000 seed weight, while insignificant associations between capsule yield (non-seed) and seed yield, plant height, capsule number, capsule length, oil yield, and morphine content were determined. The significant and high negative correlation was determined between capsule yield with oil content. According to the path analysis, the highest positive direct effect on capsule yield was seed yield $(48.202 \%)$, and the highest positive indirect effect on capsule yield was capsule width $(47.877 \%)$ via seed yield. The ten PCA components (PC1 to PC10) created $90.09 \%$ of the total variation among traits in poppy cultivars. PC1, PC2, PC3, and PC4 with values of $52.0 \%, 16.9 \%, 11.8 \%$, and $10.2 \%$, respectively contributed to the total PCA value, and plant height, capsule width, capsule number, and 1000 seed weight were found to be effective components on the yield in PCA analysis. The bi-plot analysis showed that capsule number, capsule length, seed yield, and oil yield created the same group and plant height and capsule width were another group, and these characters showed stability for the cultivars.
\end{abstract}

The according to the results of the correlation, path, and PCA, capsule width and 1000 seed weight were effective components on capsule and seed yields of the opium poppy.

Keywords: Opium poppy; Correlation; Path analysis; Principal components analysis

\section{Türk Haşhaş Çeşitlerinde (Papaver somniferum L.) Korelasyon, Path ve Temel Bileşenler Analiz Metotları Kullanılarak Özellikler Arası İlişkilerin İncelenmesi}

ESER BİLGİSI

Araştırma Makalesi

Sorumlu Yazar: Nimet KARA, E-posta: nimetkara@sdu.edu.tr, Tel: +90 (246) 2118595

Geliş Tarihi: 18 Mayıs 2015, Düzeltmelerin Gelişi: 22 Ağustos 2017, Kabul: 19 Eylül 2017 


\section{ÖZET}

Haşhaş; morfin, kodein, papaverin ve bunun gibi içermiş olduğu çok değerli alkaloidlerden dolayı önemli bir tıbbi bitkidir. Araştırma, Türkiye'de son y1llarda tescil edilmiş on beş haşhaş çeşidinde (Papaver somniferum L.) korelasyon, path ve temel bileşenler analizleri (TBA) kullanılarak kapsül verimi, bazı diğer verim ve kalite özellikleri arasındaki ilişkileri incelemek amacıyla yürütülmüştür. Denemeler, Isparta koşularında 2012/13 ve 2013/14 yıllarında tesadüf blokları deneme desenine göre 3 tekerrürlü olarak yürütülmüştür.

Araştırmada, kapsül verimi (tohumsuz) ile tohum verimi, bitki boyu, kapsül sayısı, kapsül boyu, yağ verimi ve morfin içeriği arasında önemsiz ilişkiler belirlenirken, kapsül verimi ile kapsül genişliği ve 1000 tohum ağırlığı arasında önemli pozitif ilişkiler tespit edilmiştir. Kapsül verimi ile yağ içeriği ve yağ verimi arasında önemli ve yüksek negatif ilişki belirlenmiştir. Path analizine göre, kapsül verimi üzerine en yüksek pozitif direk etkiyi tohum verimi (\% 48.202) ve en yüksek pozitif indirek etkiyi ise tohum verimi üzerinden kapsül genişliği (\% 47.877) yapmıştır. Haşhaş çeşitlerinde özellikler arasındaki toplam \% 90.09'luk farkı on temel bileşen (TB1-TB10) oluşturmuştur. Toplam temel bileşenlere TB1, TB2, TB3 ve TB4 sırasıyla, \% 52.0, \% 16.9, \% 11.8 ve \% 10.2'lik oranında katkıda yapmıştır ve bitki boyu, kapsül genişliği, kapsül sayısı ve 1000 tohum ağırlığı verim üzerine etkili özellikler olarak bulunmuştur. Bi-plot analizine göre kapsül sayısı, kapsül boyu, tohum verimi ve yağ verimi aynı grupta yer almış, bitki boyu ve kapsül genişliği ise başka bir grubu oluşturmuştur ve bu özellikler tüm çeşitlerde stabil etki yapmıştır.

Korelasyon, path ve temel bileşenler analiz sonuçlarına göre, haşhaşta kapsül ve tohum verimi üzerine en etkili özellikler kapsül genişliği ve 1000 tohum ağırlığıdır.

Anahtar Kelimeler: Haşhaş; Korelasyon; Path analizi; Temel bileşenler analizi

(C) Ankara Üniversitesi Ziraat Fakültesi

\section{Introduction}

The opium poppy is mainly evaluated by its oil and morphine content. The poppy cultivars with high alkaloid content are used for medicinal purposes, and the cultivars with low alkaloid content are evaluated for food production (Prajapati et al 2002). It is a plant which has been traditionally cultured since ancient times in Anatolia, and today half of the legal production area in the world under the control of the United Nations is located in Turkey. Turkey is a historically significant opium poppy producer with the Irano-Anatolian region accepted as the center of the origin of this crop (Tetenyi 1997). The Turkish Soil Products Office has undertaken the control of cultivation areas, products purchase, storage, and trade of poppy since 1938. After the establishment of the alkaloid factory in the Afyonkarahisar province in 1976, alkaloids are produced only by extractions from the dry poppy capsule. In Turkey, the poppy is cultivated on an area of 61591 hectares, with an annual production of 30730 tons, and an average seed yield of $500 \mathrm{~kg} \mathrm{ha}^{-1}$ (Anonymous 2015).
Although the genetic diversity of the Turkish opium poppy germplasm is a good source for improving the straw and seed yields (Gümüşcü \& Arslan 1999; Koç et al 2012), it is not a good source for the genes responsible for high morphine content (Çelik et al 2016). Because the morphine content of the cultured varieties is low (usually less than $1 \%$ ), Turkey is third in world morphine production despite being the first in the legal poppy cultivation areas in the world (Anonymous 2014). For this reason, intensive breeding studies on the development of the poppy varieties with high morphine content have been carried out for many years. In addition, the opium poppy is a crop that not only expresses great economic value for its capsules rich in opium alkaloids, but also for its seeds rich in edible oil. Because it contains no alkaloids in its seeds, the development of the varieties with both high capsule yield for alkaloid production and high seed yield for oil production is an important breeding target in the opium poppy.

The combination of capsule number, capsule weight, capsule size, and seed weight constitute 
the most desirable plant type in the opium poppy (Singh et al 2004). However, the strong positive or negative associations between the desirable traits in the opium poppy are major problems in boosting the yield and quality (Sharma et al 1981; Singh \& Khanna 1993; Singh et al 2003; Yadav et al 2006; Öztürk \& Günlü 2008). If the phenotypic and genotypic relationships among traits are related to the capsule and seed yields, and the morphine and oil contents, they can be considered as the selection criteria for breeding trials to achieve this started goal.

Correlation and path analysis is a significant statistical method to evaluate the yield and quality in plant breeding. The correlation coefficients mainly show relationships among the independent variables and the degree of linear relations among the variables; however, the correlation coefficients cannot sufficiently describe the complex relationship between the variables. Therefore, the direct and indirect effects of the various traits on both yield and quality should be known in breeding programs. For this aim, the path coefficient analysis is used to determine the amounts as the percent of direct and indirect effects of the independent variables on the dependent variable (Harman 1976; Neter et al 1983). A positive association between the seed yield with capsules per plant and capsule size was determined by Singh \& Khanna (1993) and Singh et al (2003), while a negative correlation was reported by Sharma et al (1981) in different poppy populations. Singh et al (2004) determined that there was a significant positive association among themselves in capsule size, capsules per plant, seed yield per plant, and branches per plant. The same author pointed out that there were negative direct effects and positive indirect effects on the yield of capsule weight, capsule size, capsule per plant, and plant height. However, Singh et al (2003) noticed that there were positive direct effects on the yield of these characteristics.

Principal components analysis (PCA) is a method showing the similarities and dissimilarities for explaining and defining them by simplifying complex data. PCA allows for data compression and its size reduction without any data loss. Principal components analysis is a suitable method to obtain a smaller number of artificial variables accounting for determining a new variable. This method is also a better predictor of the similarities or dissimilarities among the morphological and physiological characteristics of the plants (Aygün \& Olgun 2014). PCA is widely used in breeding programs due to it being able to explain the association among the plant characteristics (Flores et al 1998).

The aim of the study was to investigate the associations among the yield and quality traits including plant height, capsule number, capsule width, capsule length, 1000 seed weight, morphine and oil contents, and capsule and seed yields by means of correlation, and path and principal component analysis methods in the poppy.

\section{Material and Methods}

This research was conducted in the Faculty of Agriculture at Süleyman Demirel University in the Isparta province of Turkey. Isparta by having a typical continental climate in Southwestern Anatolia, is one of thirteen provinces where poppy farming is allowed by the Turkish Soil Products Office. Eleven poppy cultivars (TMO-1, TMO-2, TMO-3, TMO-T, Ofis-3, Ofis-4, Ofis-8, Ofis-95, Ofis-96, Afyon-95 and Bolvadin-95), which are registered by the General Directorate of Soil Products Office in Ankara and four poppy cultivars (Tinaztepe, Anayurt, Kemerkaya and Zaferyolu) registered by the Western Transitional Zone Agricultural Research Institute in Eskişehir were used for the genetic materials in the research. Generally, these cultivars are new varieties that have been recently years registered in Turkey.

The field experiment was conducted in a randomized complete block design with three replicates in the autumn sowing in 2012/13 and $2013 / 14$. The poppy seeds were sown at about a 0.5 $1 \mathrm{~cm}$ depth using a dibbler, on 5 and 9 October for the first (2012/13), and the second years (2013/14), respectively. The spacing used was $0.45 \times 0.15 \mathrm{~m}$, and the plot length was $5 \mathrm{~m}\left(5 \times 2.7=13.5 \mathrm{~m}^{2}\right)$ with 
6 rows. In both years, the experiments were nonirrigated at any growing stage. All the necessary cultural practices were applied identically to all the cultivars in both years. $100 \mathrm{~kg}$ nitrogen ha ${ }^{-1}$ (two equal doses at the sowing and at plant height 10$15 \mathrm{~cm}$ stages) and $30 \mathrm{~kg} \mathrm{P}_{2} \mathrm{O}_{5}$ ha $^{-1}$ (all by sowing) fertilizers were applied to the form ammonium sulfate $(21 \%)$ and triple super phosphate $(43-46 \%)$, respectively (Koç et al 2012).

The climatic data during the vegetation period (from October to the end of August) in 2012/13 and in 2013/14, showed there was a total precipitation of 555.0 and $579.9 \mathrm{~mm}$, an average temperature of 12.8 and $12.1{ }^{\circ} \mathrm{C}$, and average humidity of 58.8 and $58.3 \%$, respectively. In the years $2012 / 13$ and $2013 / 14$, the soil at a depth of $60 \mathrm{~cm}$ was low in organic matter $(1.80 \%$ and $1.66 \%$, respectively), slightly alkaline ( $\mathrm{pH} 7.5$ and 7.8 , respectively), limey $\left(9.67 \%\right.$ and $9.89 \% \mathrm{CaCO}_{3}$, respectively), and clay-loamy.

The capsules from 4 rows in the center of each plot in the full ripeness period according to the maturity stage of the cultivars were manually harvested. Capsule yield $\left(\mathrm{kg} \mathrm{ha}^{-1}\right)$, seed yield ( $\mathrm{kg}$ $\left.\mathrm{ha}^{-1}\right)$, plant height $(\mathrm{cm})$, capsule number per plant (capsule), capsule width (mm), capsule length $(\mathrm{mm})$ and 1000 seed weight $(\mathrm{g})$ were determined as described by Karabük (2012). Plant characteristics such as plant height, capsule number per plant, capsule width, and capsule length were measured from 15 plants per parcel. The oil from the poppy seeds was extracted with $n$-hexan for 6 hours using the soxhlet apparatus. For the morphine analysis, the poppy shell was dried for 24 hours at $70{ }^{\circ} \mathrm{C}$ and was powered by grinding, and was extracted with $5 \%$ acetic acid under sonication. The morphine analyses were conducted at the laboratory of Bolvadin Opium Alkaloids Factory by using the HPLC-MS/ MS apparatus.

A matrix of simple correlation coefficients among the yield and quality traits was computed. The direct and indirect effects of traits on capsule yield were made using path coefficient analysis. The principle components analysis (PCA) explained by
Harman (1976) involves a mathematical producer that transforms a number of correlated variables into a smaller number of uncorrelated variables called principal components. Correlation, path, and PCA analyses were performed according to means of two years using the SPSS v.16.0 software (Chicago, IL. USA).

\section{Results and Discussion}

The minimum, maximum values, and standard deviation for all traits (variables) determined in 15 Turkish opium poppy cultivars are presented in Table 1.

Table 1- Minimum and maximum values for the variables of opium poppy cultivars

\begin{tabular}{lll}
\hline Variables & $\begin{array}{l}\text { Minimum } \\
\text { values } \pm S D\end{array}$ & $\begin{array}{l}\text { Maximum } \\
\text { values } \pm S D\end{array}$ \\
\hline Plant height $(\mathrm{cm})$ & $80.08 \pm 7.15$ & $122.85 \pm 4.47$ \\
Capsule number (per plant) & $3.58 \pm 0.11$ & $6.48 \pm 1.09$ \\
Capsule width (mm) & $34.58 \pm 1.66$ & $46.26 \pm 3.16$ \\
Capsule length (mm) & $34.07 \pm 1.89$ & $45.05 \pm 2.49$ \\
1000 seed weight $(\mathrm{g})$ & $0.34 \pm 0.004$ & $0.43 \pm 0.006$ \\
Oil content $(\%)$ & $38.66 \pm 0.57$ & $44.00 \pm 1.00$ \\
Oil yield $\left(\mathrm{kg} \mathrm{ha}^{-1}\right)$ & $239.39 \pm 15.34$ & $558.67 \pm 23.77$ \\
Morphine content $(\%)$ & $0.47 \pm 0.005$ & $1.00 \pm 0.10$ \\
Seed yield $\left(\mathrm{kg} \mathrm{ha}^{-1}\right)$ & $575.20 \pm 21.03$ & $1325.56 \pm 51.76$ \\
Capsule yield $\left(\mathrm{kg} \mathrm{ha}^{-1}\right)$ & $457.5 \pm 22.50$ & $1149.5 \pm 38.68$ \\
\hline
\end{tabular}

SD, Standard deviation

\subsection{Correlation coefficient analysis}

The results of correlation analysis among the yield and quality traits of the opium poppy cultivars are shown in Table 2. According to the results of the correlation analysis, while there were significant and high positive correlations between capsule yield with capsule width $\left(\mathrm{r}=0.217^{*}\right)$ and 1000 seed weight $\left(\mathrm{r}=0.307^{* *}\right)$, a significant and negative correlation was determined between capsule yield with oil content $\left(\mathrm{r}=-0.290^{* *}\right)$ in the poppy. The non-significant correlations were determined between capsule yield and seed yield $(r=0.162)$ and 
morphine content $(\mathrm{r}=-0.116)$ in the opium poppy (Table 2). The correlation analysis showed that there were significant and high positive correlations between seed yield with plant height, capsule number, capsule width, capsule length, 1000 seed weight, and oil yield in the poppy. The insignificant associations were determined between seed yield and oil content $(\mathrm{r}=-0.113)$ and morphine content $(\mathrm{r}=-0.048)$. In the research, the significant and high positive correlations were determined between oil yield with seed yield, plant height, capsule number, capsule width, capsule length, and 1000 seed weight. While the significant and negative correlation between morphine content with plant height was shown, the associations between morphine content with capsule number, capsule width and capsule length were not significant (Table 2).

Generally, the bilateral relations between capsule number, capsule width, capsule length, and 1000 seed weight, were positive and significant. Srivastava \& Sharma (1987) and Singh et al (2003) noted that capsule yield, seed yield, oil yield, and morphine content were significantly affected by capsule weight, capsule size, and capsule number per plant. Sing et al (2004) reported that there were positively significant correlations between capsule yield and seed yield, capsule weight, plant height and capsule area, and among themselves. The similarity of positive association among seed yield with capsule weight and capsule area was reported by Singh et al (2003). Öztürk \& Günlü (2008) reported that positive and significant relationships were found between capsule yield with seed yield, capsule yield and oil yield. Harvest et al (2009) stated that morphine content was correlated with capsule size. The positive correlations between morphine content with size of capsule size/weight were determined by Yadav et al (2006). Positive correlations between seed yield with capsules per plant and capsule size was noticed by Singh \& Khanna (1993) and Singh et al (2003), while negative correlation was reported by Sharma et al (1981) in different populations.

\subsection{Path coefficient analysis}

Partitioning the correlation coefficient in to direct and indirect effects can be carried out through path analysis. The direct and indirect contributions on capsule yields of some of yield and quality traits in the poppy cultivars are given in Table 3 . In the research, capsule yield as a dependent variable, and seed yield, plant height, capsule number, capsule width, capsule length, 1000 seed weight, oil content, oil yield and morphine content as determinative variables, were used for the path coefficient analysis. The direct effects of the examined yield characteristics (except for oil yield and morphine content) on capsule yield in the poppy cultivars were positive. The highest positive direct effect on

Table 2- A matrix of simple correlation coefficients (r) for the estimated variables of opium poppy

\begin{tabular}{|c|c|c|c|c|c|c|c|c|c|c|}
\hline Variables & $\begin{array}{l}\text { Capsule } \\
\text { yield }\end{array}$ & $X_{1}$ & $X_{2}$ & $X_{3}$ & $X_{4}$ & $X_{5}$ & $X_{6}$ & $X_{7}$ & $X_{8}$ & $X_{9}$ \\
\hline Seed yield $\left(\mathrm{X}_{1}\right)$ & $0.162^{\text {ns }}$ & 1.000 & & & & & & & & \\
\hline Plant height $\left(\mathrm{X}_{2}\right)$ & $0.003^{\mathrm{ns}}$ & $0.558 * *$ & 1.000 & & & & & & & \\
\hline Capsule number $\left(\mathrm{X}_{3}\right)$ & $-0.183^{\mathrm{ns}}$ & $0.431 * *$ & $0.203^{\mathrm{ns}}$ & 1.000 & & & & & & \\
\hline Capsule width $\left(\mathrm{X}_{4}\right)$ & $0.217^{*}$ & $0.743 * *$ & $0.714 * *$ & $0.287 * *$ & 1.000 & & & & & \\
\hline Capsule length $\left(\mathrm{X}_{5}\right)$ & $-0.025^{\mathrm{ns}}$ & $0.657 * *$ & $0.146^{\mathrm{ns}}$ & $0.204^{\mathrm{ns}}$ & $0.248 *$ & 1.000 & & & & \\
\hline 1000 seed weight $\left(X_{6}\right)$ & $0.307 * *$ & $0.701 * *$ & $0.357 * *$ & $0.152^{\text {ns }}$ & $0.558 * *$ & $0.539 * *$ & 1.000 & & & \\
\hline Oil content $\left(\mathrm{X}_{7}\right)$ & $-0.290 * *$ & $-0.113^{\mathrm{ns}}$ & $-0.069^{n s}$ & $-0.062^{\mathrm{ns}}$ & $-0.245^{*}$ & $0.076^{\mathrm{ns}}$ & $-0.142^{\mathrm{ns}}$ & 1.000 & & \\
\hline Oil yield $\left(\mathrm{X}_{8}\right)$ & $0.110^{\mathrm{ns}}$ & $0.988 * *$ & $0.545 * *$ & $0.426^{* *}$ & $0.708 * *$ & $0.670 * *$ & $0.682 * *$ & $0.039^{\text {ns }}$ & 1.000 & \\
\hline Morphine content $\left(\mathrm{X}_{9}\right)$ & $-0.116^{\mathrm{ns}}$ & $0.048 \mathrm{~ns}$ & $-0.241^{*}$ & $-0.033^{\mathrm{ns}}$ & $-0.083^{\mathrm{ns}}$ & $0.084^{\mathrm{ns}}$ & $0.153^{\mathrm{ns}}$ & $-0.180^{\mathrm{ns}}$ & $0.027^{\mathrm{ns}}$ & 1.000 \\
\hline
\end{tabular}

*,**, significant at $\mathrm{P}<0.05$ and $\mathrm{P}<0.01$ probability levels, respectively; ns, non-significant 
capsule yield was seed yield (48.202\%), followed by oil content $(36.215 \%)$, plant height $(5.946 \%)$, capsule number $(5.380 \%)$, capsule length $(4.301 \%)$, 1000 seed weight $(3.685 \%)$, and capsule width $(1.054 \%)$, respectively (Table 3 ). Capsule width (47.877\%), 1000 seed weight $(47.368 \%)$, capsule length $(46.913 \%)$, capsule number $(46.837 \%)$, and plant height $(46.539 \%)$ had the highest indirect contributes on capsule yield via seed yield (Table 3 ). These results indicate that the direct and indirect effects of plant traits including plant height, capsule number and capsule length on capsule yield were higher than the other yield components. These results were similar to the findings of Singh \& Khanna (1993) and Singh et al (2004). Shukla \& Khanna (1987) and Singh et al (2003) stated that the direct and indirect contribution on yield of plant height and capsule weight/length were positive. Öztürk \& Günlü (2008) determined that the direct and indirect effects on seed yield of capsule yield were both positive and minimal.

\subsection{Principal components analysis}

The main target in the principal components is determining the maximum amount of variance with the lowest number of components. Principal component analysis assists in explaining the underlying data, and designing a small amount of uncorrelated variables. Besides, it reveals the data of the orthogonal eigenvectors on the correlation matrix in the variables. Each principal component explains its largest percent of the total variation. The first principal component covers the largest percent of the total variation. The data presented in

Table 3- Path coefficient (direct and indirect effects) of the yield components on capsule yield of opium poppy

\begin{tabular}{lllllllllll}
\hline & \multicolumn{1}{l}{ Direct effects } & \multicolumn{1}{c}{ Indirect Effects } \\
\cline { 2 - 11 } Variables & Capsule yield & $X_{1}$ & $X_{2}$ & $X_{3}$ & $X_{4}$ & $X_{5}$ & $X_{6}$ & $X_{7}$ & $X_{8}$ & $X_{9}$ \\
\hline Seed yield & 6.280 & & -0.247 & -0.132 & 0.075 & -0.245 & 0.237 & -0.072 & -5.648 & -0.013 \\
$\left(\mathrm{X}_{1}\right)$ & 48.202 & & 1.917 & 1.029 & 0.585 & 1.905 & 1.841 & 0.563 & 43.845 & 0.100 \\
\hline Plant height & 0.442 & 3.464 & & -0.062 & 0.072 & -0.054 & 0.120 & -0.044 & -3.116 & 0.065 \\
$\left(\mathrm{X}_{2}\right)$ & 5.946 & 46.539 & & 0.838 & 0.974 & 0.733 & 1.624 & 0.593 & 41.871 & 0.879 \\
\hline Capsule & 0.307 & 2.677 & -0.089 & & 0.029 & -0.076 & 0.051 & -0.039 & -2.436 & 0.008 \\
number $\left(\mathrm{X}_{3}\right)$ & 5.380 & 46.837 & 1.571 & & 0.509 & 1.332 & 0.901 & 0.697 & 42.615 & 0.154 \\
\hline Capsule width & 0.101 & 4.609 & -0.316 & -0.088 & & -0.092 & 0.188 & -0.156 & -4.051 & 0.022 \\
$\left(\mathrm{X}_{4}\right)$ & 1.054 & 47.877 & 3.284 & 0.915 & & 0.961 & 1.961 & 1.626 & 42.083 & 0.233 \\
\hline Capsule length & 0.373 & 4.076 & -0.064 & -0.062 & 0.025 & & 0.182 & 0.048 & -3.832 & -0.022 \\
$\left(\mathrm{X}_{5}\right)$ & 4.301 & 46.913 & 0.743 & 0.721 & 0.289 & & 2.099 & 0.556 & 44.111 & 0.262 \\
\hline 1000 seed & 0.338 & 4.349 & -0.158 & -0.046 & 0.056 & -0.201 & & -0.090 & -3.898 & -0.041 \\
weight $\left(\mathrm{X}_{6}\right)$ & 3.685 & 47.368 & 1.722 & 0.510 & 0.616 & 2.193 & & 0.989 & 42.461 & 0.451 \\
\hline Oil content & 0.640 & -0.703 & 0.030 & 0.019 & -0.024 & -0.028 & -0.048 & & -0.224 & 0.048 \\
$\left(\mathrm{X}_{7}\right)$ & 36.215 & 39.791 & 1.726 & 1.082 & 1.404 & 1.597 & 2.715 & & 12.694 & 2.766 \\
\hline Oil yield $\left(\mathrm{X}_{8}\right)$ & -5.719 & 6.131 & -0.241 & -0.131 & 0.071 & -0.250 & 0.230 & 0.025 & & -0.007 \\
& 44.652 & 47.869 & 1.883 & 1.022 & 0.561 & 1.955 & 1.801 & 0.196 & & 0.057 \\
\hline Morphine & -0.271 & 0.296 & 0.106 & 0.010 & -0.008 & -0.031 & 0.051 & -0.115 & -0.154 & \\
content $\left(\mathrm{X}_{9}\right)$ & 25.917 & 28.349 & 10.211 & 0.959 & 0.805 & 3.009 & 4.940 & 11.033 & 14.774 & \\
\hline
\end{tabular}

The first lines is path coefficient (pc) and the second lines is path percentage (\%) 
Table 4 demonstrated that an increase in number of components was associated with a decrease in the Eigen values. This trend reached its maximum at four factors or components. With 5.202, the first principal component covers $52.0 \%$ of the total variance. With $1.685,1.175$ and 1.024 the second, third, and fourth principal components explain $16.9 \%, 11.8 \%$ and $10.2 \%$ of the total variance, and the four principal components explain $90.9 \%$ of the total variance (Table 4). In the first principal component, plant height, capsule number, width and length of the capsule, seed yield, 1000 seed weight, and oil yield could be considered to be the effective components on yield, and they have the same sign and their terms were not close to zero. In the second principal component, the terms of capsule length, capsule yield, 1000 seed weight (negative sign) and plant height, and capsule number and oil content (positive sign) were not close to zero. The third PCA showed a positive effect on capsule length, 1000 seed weight, oil content oil yield, and morphine content, and a negative effect on plant height, capsule number, capsule width, and capsule yield were not close to zero. The fourth PCA showed positive effects on capsule number, capsule width, seed yield, and morphine content, and a negative effect on plant height, capsule length, capsule yield, 1000 seed weight, and oil content and oil yield were not close to zero (except for in seed yield, 1000 seed weight and oil yield). Özdamar (1999) demonstrated that the main component describing $67.0 \%$ of the data is sufficient to determine the main characteristics in the principal component analysis. In a study conducted on wheat by Hailegiorgis et al (2011), Beheshtizadeh et al (2013), Olgun et al (2014) and Priya et al (2014) it was stated that the principal component was explained in $80.0 \%$, $76.0 \%, 90.8 \%$, and $75.0 \%$, respectively, and rates with an association among the quality characteristics as cumulative. The highest effective components were plant height, width and length of capsule, capsule number, and 1000 seed weight on yield in the PCA.

The bi-plot analysis showing the stability of the cultivars and yield components are given in Figure 1. The higher performance and stability; similarity/ dissimilarity in the cultivars and yield components

Table 4- Eigen values of the correlation matrix and principal component analysis for the variables in opium poppy

\begin{tabular}{lrrrrrrrrrr}
\hline Variables & $P C 1$ & \multicolumn{1}{c}{$P C 2$} & $P C 3$ & $P C 4$ & $P C 5$ & $P C 6$ & $P C 7$ & $P C 8$ & $P C 9$ & $P C 10$ \\
\hline Seed yield $\left(\mathrm{X}_{1}\right)$ & 0.430 & -0.074 & 0.070 & 0.040 & 0.027 & 0.088 & 0.313 & 0.297 & -0.283 & -0.727 \\
Plant height $\left(\mathrm{X}_{2}\right)$ & 0.327 & 0.375 & -0.167 & -0.095 & 0.573 & -0.111 & -0.512 & -0.131 & -0.309 & -0.011 \\
Capsule number $\left(\mathrm{X}_{3}\right)$ & 0.295 & 0.247 & -0.370 & 0.313 & -0.641 & 0.116 & -0.391 & 0.193 & 0.049 & 0.013 \\
Capsule width $\left(\mathrm{X}_{4}\right)$ & 0.398 & 0.050 & -0.155 & 0.193 & 0.203 & 0.444 & 0.260 & -0.476 & 0.495 & 0.012 \\
Capsule length $\left(\mathrm{X}_{5}\right)$ & 0.380 & -0.114 & 0.365 & -0.135 & 0.110 & -0.292 & -0.223 & 0.416 & 0.605 & 0.071 \\
1000 seed weight $\left(\mathrm{X}_{6}\right)$ & 0.329 & -0.339 & 0.344 & -0.042 & -0.342 & -0.290 & -0.181 & -0.616 & -0.203 & -0.038 \\
Oil content $\left(\mathrm{X}_{7}\right)$ & -0.037 & 0.456 & 0.366 & -0.622 & -0.254 & 0.429 & -0.073 & -0.069 & 0.035 & -0.098 \\
Oil yield $\left(\mathrm{X}_{8}\right)$ & 0.428 & -0.008 & 0.125 & -0.036 & -0.021 & 0.154 & 0.338 & 0.232 & -0.389 & 0.675 \\
Morphine content $\left(\mathrm{X}_{9}\right)$ & -0.159 & 0.030 & 0.602 & 0.608 & 0.131 & 0.369 & -0.270 & 0.061 & -0.108 & -0.005 \\
Capsule yield $(\mathrm{Y})$ & 0.004 & -0.674 & -0.207 & -0.275 & 0.084 & 0.506 & -0.381 & 0.123 & -0.063 & 0.212 \\
\hline & & & & & & & & & & \\
\hline Eigen value & 5.202 & 1.685 & 1.175 & 1.024 & 0.388 & 0.338 & 0.115 & 0.058 & 0.009 & 0.000 \\
Proportion & 0.520 & 0.169 & 0.118 & 0.102 & 0.039 & 0.034 & 0.012 & 0.006 & 0.001 & 0.000 \\
Cumulative (\%) & 0.521 & 0.689 & 0.806 & 0.909 & 0.948 & 0.993 & 0.999 & 1.000 & 1.000 & 1.000 \\
\hline
\end{tabular}


were explained in detail. The $\mathrm{PC} 1$ shows a high value and performance, the PC2 assigns the stability in the cultivars and yield components. In the cultivars, varieties 6,7 , and 13 have a higher capacity and stability for yield components. Moreover, the cultivars 3,6 and 7 , cultivars 11 and 13 , the cultivars 1 and 15 , and the cultivars $2,4,8,9$, and 10 joined the same groups. In yield components, plant height and capsule width created the same group, and capsule number, capsule length, seed yield and oil yield were in another similar group, and they both showed stability for the cultivars, the others were placed in a separate group. In a study conducted on white clover by Aygün \& Olgun (2014), it was explained that the plant characteristics and genotypes were classified in five specific groups on plant height using the PCA. In studies conducted on wheat by Çiftçi \& Yağdı (2012) and Priya et al (2014), it was determined that the plant genotypes were classified in five groups.

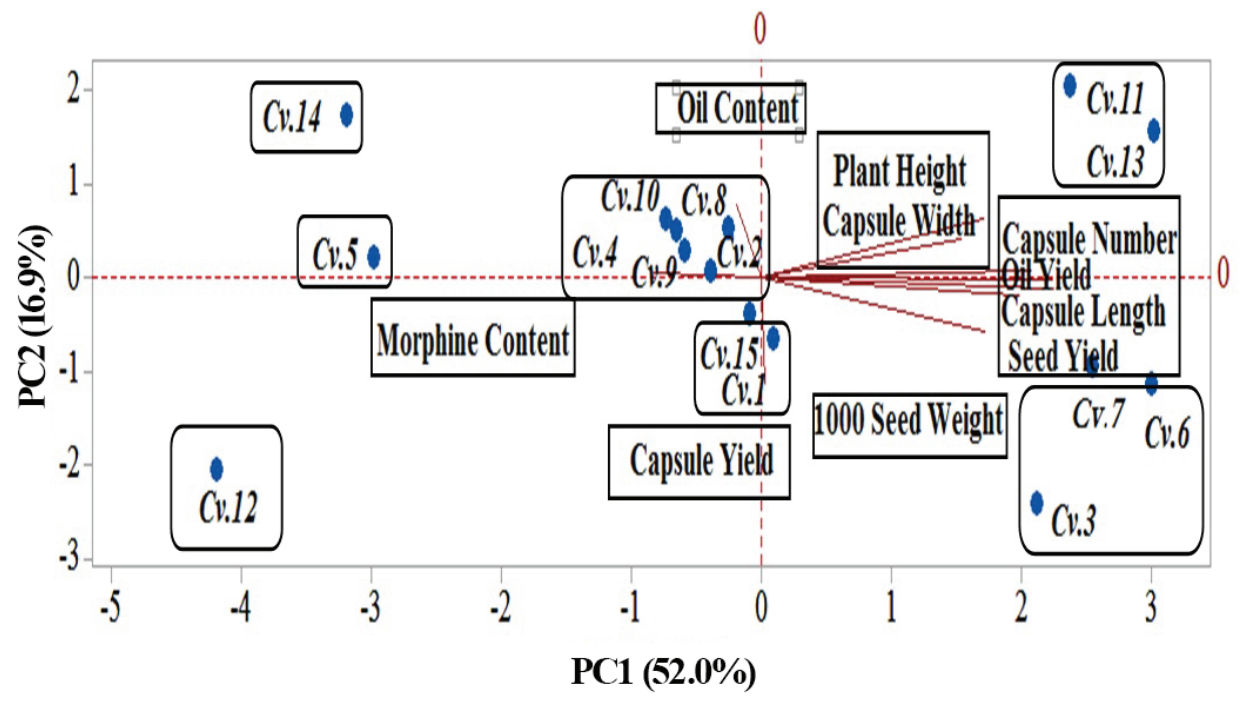

Figure 1- Bi-plot analysis showing stability and the variables in opium poppy cultivars (Codes of cultivars: Cv1.TMO-1, Cv2.TMO-2, Cv3.TMO-3, Cv4.TMO-T, Cv5.Ofis-3, Cv6.Ofis-4, Cv7.Ofis-8, Cv8.Ofis-95, Cv9. Ofis-96, Cv10.Afyon-95, Cv11.Bolvadin-95, Cv12.Tınaztepe, Cv13.Anayurt, Cv14.Kemerkaya and Cv15. Zaferyolu)

\section{Conclusions}

As a result, high positive and significant associations were determined between capsule yield with capsule width and 1000 seed weight. The associations between seed yield with plant height, capsule number, capsule width, capsule length, 1000 seed weight and oil yield were highly positive and significant. There were insignificant and negative correlations between capsule yield and capsule number, capsule length and morphine content, but the association between capsule yield with oil content was negative and significant.
While the effects on capsule yield of plant height, capsule number, capsule length and capsule width were positive but low, the direct effects on capsule yield of seed yield and oil content were positive and high. The indirect effects of capsule width, 1000 seed weigh, capsule number and plant height, respectively, on capsule yield via seed yield were high and positive.

The PCA analysis showed that ten components accounted for about $90.9 \%$ of the total variation among traits in the poppy. The PC1 contributed the most to the total variation, followed by PC2, PC3, 
and PC4. According to the bi-plot analysis, capsule number, capsule length, seed yield, and oil yield created the same group, and they showed stability in the cultivars. Different statistical techniques have been used in modeling crop yields, including correlation, path analysis, and PCA. Since different traits have had an important role according to the statistical techniques of opium poppy cultivars, different criteria can be used for the improvement of capsule and seed yields. Thus, the results showed that capsule width and 1000 seed weight were effective components on capsule and seed yields.

\section{Acknowledgements}

The authors thank the Directorate of the Western Transitional Zone Agricultural Research Institute and the General Directorate of the Soil Products Office for providing the poppy cultivars and the morphine analysis.

\section{References}

Anonymous (2014). Turkish Soil Product Office, Opium Poppy Report 2014, Ankara

Anonymous (2015). Turkey Statistically Office-2015, Ankara

Aygün C \& Olgun M (2014). Determination of genotypic performances of white clover (Trifolium repens L.) collected from natural pastures. Artvin Çoruh University Journal of Forestry Faculty 15(1): 73-84

Beheshtizadeh H, Rezaie A, Rezaie A \& Ghandi A (2013). Principal components analysis and determination of the selection criteria in bread wheat (Triticuma aestivum L.) genotypes. International Journal Agriculture and Crop Science 5(18): 2024-2027

Çelik I, Camcı H, Köse A, Çelikoğlu K F, Doğanlar S \& Frary A (2016). Molecular genetic diversity and association mapping of morphine content and agronomic traits in Turkish opium poppy (Papaver somniferum L.) germplasm. Molecular Breeding 36: 46-56

Çiftçi E A \& Yağdı K (2012). Study of genetic diversity in wheat (Triticum aestivum) varieties using random amplified polymorphic DNA (RAPD) analysis. Turkish Journal of Field Crops 17(1): 91-95
Gümüşçü A \& Arslan N (1999). Comparing yield and yield components of some selected poppy (Papaver somniferum L.) lines. Turk Journal of Agriculture and Forestry 23(4): 991-997

Hailegiorgis D, Mesfin M \& Genet T (2011). Genetic divergence analysis on some bread wheat genotypes grown in Ethiopia. Journal of Central European Agriculture 12(2): 344-352

Harman H H (1976). Modern Factor Analysis. $3^{\text {rd }}$ Ed. University of Chicago Press, Chicago, pp. 376

Harvest T, Brown P H, Fist A, Gracie A, Gregory D \& Koutoulis A (2009). The latex capacity of opium poppy capsules is fixed early in capsule development and is not a major determinant in morphine yield. Annual Applied Biology 154: 251-258

Flores E, Moreno M T \& Cubero J I (1998). A comparison of univariate and multivariate methods to analyze environments. Field Crops Research 56: 271-286

Karabük B (2012). The effects of nitrogen fertilization and sowing methods on agricultural and quality of poppy (Papaver somniferum L.) varieties. $\mathrm{PhD}$ Thesis, Ondokuz Mayıs University Institute of Natural and Applied Science (unpublished ) (in Turkish,), Samsun

Koç H, Ülker R, Güneş A, Gümüşçü G, Ercan B, Topal İ, Kara İ, Özdemir F, Keleş R \& Bayrak H (2012). Determination of some local opium poppy genotypes according to seed and capsule yields. Medicinal and Aromatic Plants Symposium 13-15 September, Tokat, Turkey, pp. 255-259 (in Turkish)

Neter J, Wassermann W \& Kutner M H (1983). Applied Linear Regression Models. pp. 1-150, U.S.A

Olgun M, Yorgancılar Ö, Başçiftçi Z B \& Ayter N G (2014). Evaluation of some quality components in bread wheat (Triticum aestivum L.) by different statistical methods. Süleyman Demirel University Journal of Agriculture Faculty 9(2): 59-68

Özdamar K (1999). Statistical Data Analysis with Computer Programs. Vol: I-II, Kaan Press, 2 $2^{\text {nd }}$ Edition, Eskisehir. 548 pp

Öztürk Ö \& Günlü H (2008). Determining relationships amongst morphine, capsule and oil yield using path coefficient analysis in poppy (Papaver somniferum L.). Asian Journal of Chemistry 20(4): 2979-2988

Prajapati S, Bajpai S, Singh D, Luthra R, Gupta M M \& Kumar S (2002). Alkaloid profiles of the Indian land races of the opium poppy Papaver somniferum L. Genet Research Crop Evaluation 49: 183-188 
Priya B, Das B, Satyanarayana N H, Mukherjee S \& Sarkar K K (2014). Genetic diversity of wheat genotypes based on principal component analysis in gangetic alluvial soil of West Bengal. Journal of Crop and Weed 10(2): 104-107

Sharma J R, Misra H O, Nair R V, Srivastava R K, Singh O P \& Srivastava D P (1981). Phenological distribution of latex yield and plant type concept in opium poppy (Papaver somniferum L.). Indian Drug 19: 64-69

Shukla S \& Khanna K R (1987). Genetic association in opium poppy (Papaver somniferum L.). Indian Journal AgricScience 57(3): 147-151

Singh S P \& Khanna K R (1993). Path coefficient analysis for opium and seed yield in opium poppy (Papaver somniferum L.). Genetika 25(2): 119-128

Singh S P, Yadav H K, Shukla S \& Chatterjee A (2003). Studies on different selection parameters in opium poppy (Papaver somniferum L.). Journal Medicinal and Aromatic Plant Science 25: 8-12

Singh S P, Shukla S \& Yadav H K (2004). Genetic studies and their implication to breed desired plant type in opium poppy (Papaver somniferum L.). Genetika 36(1): 69-81

Srivastava R K \& Sharma J R (1987). Genetic changes in a population subjected to biparental mating in opium poppy. Indian Journal of Genetics and Plant Breeding 47(3): 319-327

Tetenyi P (1997). Opium poppy (Papaver somniferum L.) botany and horticulture. Horticulture Review 19: 373408

Yadav H K, Shukla S \& Singh S P (2006). Genetic variability and interrelationship among opium and its alkaloids in opium poppy (Papaver somniferum L.). Euphytica 150: 207-214 